\title{
Can Boko Haram Constitute a Threat to European Security?
}

\author{
Tibor BABOS ${ }^{1}$ - Gábor SINKÓ2
}

Imbalance, poverty, dictatorship's expansionary ambition and the relevant cultural background serve as fertile ground to expand terrorism. ${ }^{3}$

Tibor Babos

\begin{abstract}
In this study, the authors seek to address the question whether Boko Haram can constitute a threat to European security. Toanswer this question, one mustanalyse recent Nigerian migration patterns to Italy, actual reports, peer-reviewed academic works, a wide variety of regional journals and media articles. By evaluating all available research sources, it can be concluded that the answer is not as clear-cut as one might thinkat first glance. On the one hand, we could argue that a terrorist group like Boko Haram cannot constitute a serious European security threat, since the majority of Nigerians arriving in Europe seems to have decided to flee their country of origin due to economic, social and security reasons, therefore, these migrants have nothing to do with terrorism. On the other hand, we could also argue that Boko Haram can pose a threat to European security, by taking advantage of migration flows and inserting its own soldiers, thus creating terrorist cells within them. We have found plenty of evidences related to the terrorist organisation's increased use of women as soft targets and the potential re-radicalisation of traumatised children in Europe. Since its alignment with ISIL in 2015, there has been growing concern that Boko Haram could follow suit with focusing its efforts on refugees, infiltrating migration flows and thereby creating a significant security risk to Europe. However, in recent years the number of Nigerian migrants arriving in Europe has been decreasing, which could be justified by tighter links between African and European governments and by stronger European control. If this continuous cooperation and tight internal European border security andpolice procedures are to remain, there is less chance for Boko Haram to constitute athreat toEuropean security.
\end{abstract}

Keywords: Boko Haram, European security, Nigeria, migration, infiltration

Associate Professor, Donát Bánki Faculty of Mechanical and Safety Engineering, Director of Óbuda University Center for Safety Sciences, Honorary Professor of Óbuda University; e-mail: babos@uni-obuda.hu 2 Doctoral student, Óbuda University Doctoral School of Security Sciences; e-mail: sinko.gabor@stud.uniobuda.hu

3 T Babos, The Five Central Pillars of European Security (Brussels: NATO Public Diplomacy Division, Budapest: Strategic and Defense Research Center, Oberammergau: NATO School, Budapest: Charta press, 2007). 


\section{Introduction}

9/11 not only shook the world but also caused significant change in securitypolicy perceptions. What previously were only potential risk factors are now everydaythreats. Following the terrorist attacks, the quantitative indicators and distribution of theworld's security factors did not change; however, the quality and nature did. Looking at targets, it is evident that military sites are only secondary and attacks against civilians, besides military targets, directly and significantly revised the previous rules of warfare. The vulnerability ofdeveloped countries did not diminish; however, national and state defensive systems required fundamental revisions. ${ }^{4}$

We can be certain that fanatics with relative power status are prepared and able to sacrifice people - bothfollowers and victims - for their cause. Considering that the majority of terror planners sendmisguided or threatened women and young men to commit suicide attacks, taking stepsagainst them is extremely difficult. The after-effects of major attacks mean economic andsocietal changes on the national level. Anti-terrorism campaigns also demand increased expenditures and tax resources worldwide, which bring about numerousrestrictions on mass transport and strategically significant facilities. ${ }^{5}$

One of the most dominant mattersof recent European history is the large inflow of migrants and refugees arriving in the European Union (EU) from all across the world. According to a 2018 Eurostat spreadsheet, the number of people applying for asylum in the EU quadrupled between 2013 and 2015. ${ }^{6}$ Moreover, from the latter year migration has featured more prominently in public discussions and thereby entered the collective consciousness of European citizens and has remained to be one of the most worrisome issues in the following years. ${ }^{7}$

There has been much emphasis on the influx of refugees coming to the EU from the Middle East, especially from Syria due to the civil war that is still raging in the country. Nevertheless, Africa also deserves special attention, since nearly a threefold increase could be witnessed in the number of asylum applicants comparing data in 2008 and $2018 .^{8}$ Furthermore, while there were fewer Iraqi and Syrian refugees arriving in the EU after the peak of the European migrant crisis in 2015, the inflow of African asylum seekers continued to show a steady increase. Considering the number of asylum applications between 2008 and 2017, refugees from Africa regarded Italy, Franceand Germany as the most favourable target countries. Additionally, the Europeanpopulation of migrants from Sub-Saharan Africa has grown by almost a million between 2010 and 2017. ${ }^{9}$

\section{Ibid.}

Ibid.

Eurostat, ‘Asylum and new asylum applicants: monthly data’, 2018.

European Commission, Standard Eurobarometer 89 - Wave EB89.1. Kantar Public Brussels on behalf of TNS opinion \& social, Survey requested and co-ordinated by the European Commission, Directorate-General for Communication, Fieldwork, March 2018.

$8 \quad H$ Weber, 'CanViolent Conflicts Explain the Recent Increase in the Flow of Asylum Seekers From Africa Into Europe?’, Journal of Immigrant \& Refugee Studies 17, no 4 (2019), 405-424.

9 Pew Research Center, 'At Least a Million Sub-Saharan Africans Moved to Europe Since 2010', 22 March 2018. 
In this article, the authors seek to address the question whether one of themost lethal terrorist organisations, Boko Haram constitutes a threat to European security. According to previous studies, terrorism could be consideredone of the most perilous phenomena from the perspective of global security and peace. ${ }^{10}$ It seems evident that in the $21^{\text {st }}$ century, which is increasingly characterised by changing geopolitics and globalisation, exchanges and flows have largely been facilitated. Besides being a force for good, they have been exploited by terrorist groups for network-developmental and recruitment purposes. ${ }^{11}$

Today the Nigerian Jama'atu Ahlis-Sunna Lidda’Awati Wal-Jihad (People Committed to the Prophet's Teachings for Propagation and Jihad) or as more commonly known, Boko Haram continues to pose a major threat both locally and globally, especially after pledging allegiance to the Islamic State of Iraq and the Levant (ISIL) in 2015. ${ }^{12}$ While the spillover of its military activities to neighbouring countries has had an effect on regional security, the authors intend to scrutinise if there could be a potential link between Boko Haram and European security byanalysing reports, peer-reviewed academic works, journals and recent Nigerian migration patterns to the most important target country by the Mediterranean Sea, Italy. Additionally, despite them being fragmentary or politicised, media articles have been utilised with the intention of painting a clearer image.

The thesis of the study is that not only does Boko Haram constitute a threat to regional security in Nigeria and its neighbouring countries but also to Europe. In order to verify this claim, firstly the authors examine Nigerian migration patterns with their potential push and pull factors, perform a background analysis of Boko Haram and review the major historical events in the development of the terrorist organisation. The study then analyses and evaluates the European aspects of the group and finally draws conclusions and makes recommendations with regard to Boko Haram.

\section{Background}

Since the beginning of the European migrant crisis, high numbers of refugees and migrants have started arriving in the EU. Over the years, Italy could be regarded as the most popular destination country for African nationals traveling through the Mediterranean Sea. ${ }^{13}$ Most of the people who arrived in Italy in the period of 2014-2015 were of Syrian, Nigerian, Sudanese, Gambian, Ethiopian, Somali and Bangladeshi origin. ${ }^{14}$ Table 1 illustrates the number of African migrants coming to Italy by sea between 2015 and 2018, coupled with

10 C Flint, Introduction to Geopolitics (New York: Routledge 2011); A R Moten, 'Understanding Terrorism: Contested Concept, Conflicting Perspectives and Shattering Consequences’, Intellectual Discourse 18, no 1 (2010), 35-63; L Pettiford and D Harding, Terrorism: The New World War (London: Arcturus Publishing Limited, 2003).

11 C Isike and E Isike, 'Migration and the geopolitics of Boko Haram terrorism in Nigeria', Strategic Review for Southern Africa 40, no 2 (2018), 34-51.

12 I Inyang, ‘Boko Haram is broke-UN Envoy’, Daily Post, 08 February 2017.

13 European Commission, Standard Eurobarometer 89; J Besenyő, 'Fences and Border Protection: The Question of Establishing Technical Barriers in Europe’, AARMS 16, no 1 (2017), 77-87.

14 IOM, 'Migration Trends Across the Mediterranean: Connecting the Dots', Altai Consulting for IOM MENA Regional Office, June 2015. 
their countries of origin. As it can be seen, besides Eritrea, Nigeria was responsible for the largest inflow of irregular refugees and migrants to Italy with its nearly 78,000 people in the period of 2015-2017. By 2018, the number of Nigerians arriving in Italy has dropped significantly, since only 1,250 people were registered at the country's shore. ${ }^{15}$ In the last two years, however, Nigeria was not even included in the list of the ten most common nationalities of arrivals in Italy. ${ }^{16}$

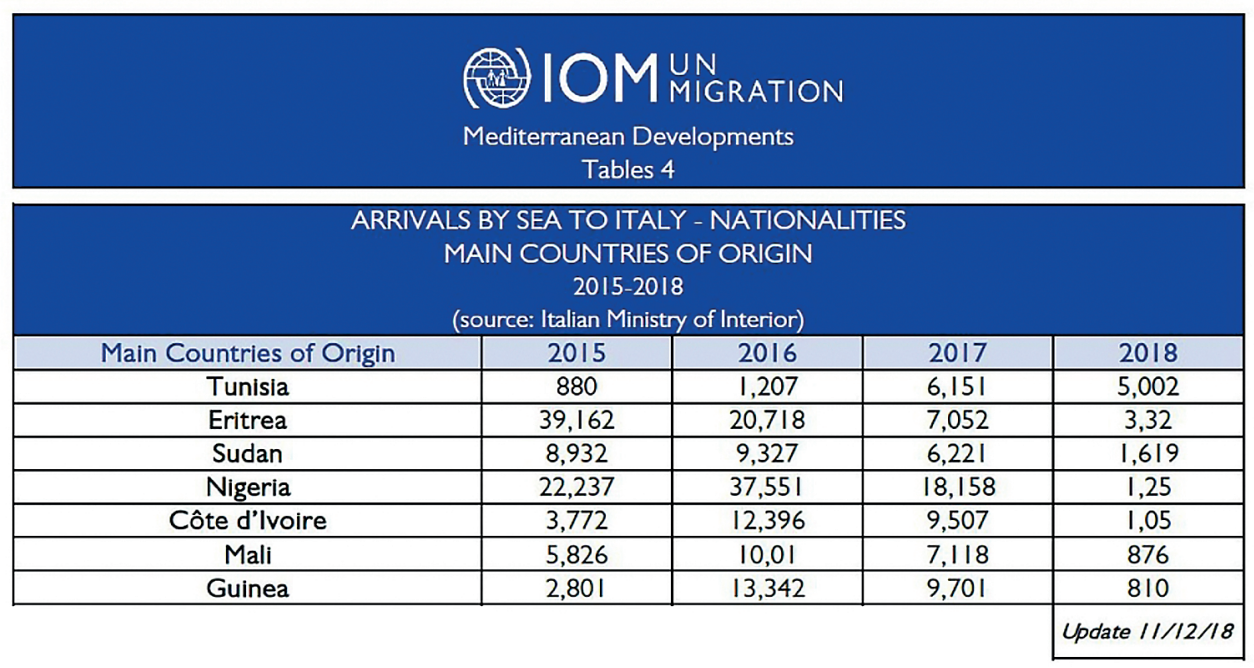

Table 1: Arrivals of African migrants by sea to Italy between 2015 and 2018

Source: IOM UN Migration, 'Mediterranean Migrant Arrivals'.

As a consequence of the increase in the number of Nigerian illegal migrants and refugees between 2015 and 2018, tougher migration policies have been adopted by European leaders with the intent of regulating and controlling migration flows to the continent. In search of higher standard of living, Nigerians had to come up with an alternative path for getting into Europe, which was ultimately found in the CentralMediterranean route. ${ }^{17}$ It has been reported to be one of the most dominant crossovers for African nationals, particularly those emigrating from either the north or the west of the continent. ${ }^{18}$ The spike in the arrivals of Nigerian migrants in Italy in 2016 might be explained by Boko Haram pledging allegiance to ISILthe previous year. This view is supported bythe results of a 2015 Global Attitudes Survey, according to which 66 per centof Nigerians had an unfavourable opinion

15 IOM UN Migration, 'Mediterranean Migrant Arrivals Reach 110,833 in 2018; Deaths Reach 2,160', 12 November 2018.

16 UNHCR, 'Italy Sea Arrivals Dashboard', December 2019; UNHRC, 'Italy Sea Arrivals Dashboard', October 2020.

17 K Hooper, 'European Leaders Pursue Migration Deals with North African Countries, Sparking Concerns about Human Costs’, Migration Policy Institute, 17 December 2017.

18 IOM, 'World Migration Report 2018’; DTM, 'Libya’s Migrant Report', Flow Monitoring, Round 17, JanuaryFebruary 2018. 
of the Islamic militant group in Iraq and Syria. ${ }^{19}$ Nevertheless, while Boko Haram is mostly active in the northeast, the majority of Nigerian refugees coming to the EU appear to have originated from Benin City, which is situated in the south of the country. ${ }^{20}$

When studying the causes of Nigerian migration, it is elementary to scrutinise its potential push and pull factors. These can either be applicable for individuals or groups and are simultaneously present with some of them being more or less significant depending on context. ${ }^{21}$ There are elements capable of pushing refugees away from their country of origin and there are factors that can pull them in their destination countries. Political instability, human rights abuses and government repression, for instance, are thought to have largely contributed to the increase in the inflow of Nigerian migrants to Europe. ${ }^{22}$ Corruption is another often-cited element that may have led to the inability of the Nigerian Government to provide basic services to its citizens, especially in the northern part of the country, where the influence of Boko Haram is the strongest. ${ }^{23}$

Economic factors, such as the lack of job opportunities and poverty feature as major causes of Nigerian migration, as well. When poverty headcount rates in some of the northern (Yobe 72.34 per cent, Gombe 62.31 per cent, Adamawa 75.41 per cent) and southern states (Lagos 4.5 per cent, Delta 6 per cent, Edo 12 per cent) are compared, huge differences can be seen. ${ }^{24}$ Illiteracy constitutes another problem with the amount of illiterate youth being at 83 per cent in Boko Haram-ridden Borno state. ${ }^{25}$ Besides, one of the most important responsibilities of a government is the protection of its citizens' lives. If it fails to do so then a reasonable response from the population could be migration to another country that is able to provide security. In this sense, terrorism in the form of religious and political insurgencies in Nigeria can also be considereda push factor. ${ }^{26}$

19 J Poushter, 'In nations with significant Muslim populations, much disdain for ISIS', Pew Research Center, 17 November 2015.

20 S O’Grady, 'Nigerian Migrants Get a Welcome Home. Jobs Are Another Story’, New York Times, 08 January 2018; BBC, ‘A Nigerian’s nightmare failed bid to migrate to Europe’, 28 April 2017; J Agbakwuru, 'FG inaugurates Migration Centre in Edo’, The Vanguard Nigeria, 07 March 2018.

21 A Loada and P Romaniuk, 'Preventing Violent Extremism in Burkina Faso: Toward National Resilience Amid Regional Insecurity’, Global Center on Cooperative Security, June 2014.

22 M O Okeyim, The State and Migration of Nigerians into the European Union to Live in Spain (Doctoral thesis, University of Alicante, 2012); A Botha, 'Radicalisation in Kenya: Recruitment to al-Shabaab and the Mombasa Republican Council’, ISS Paper 265, September 2014.

23 R C Cachalia, U Salifu and I Ndung'u, 'The dynamics of youth radicalisation in Africa: Reviewing the current evidence', ISS Paper 296, August 2016.

24 NBS, '2019 Poverty and Inequality in Nigeria: Executive Summary', National Bureau of Statistics, 2019.

25 D E Agbiboa, 'The Nigerian burden: religious identity, conflict and the current terrorism of Boko Haram', Conflict, Security \& Development 13, no 1 (2013), 1-29.

26 B Barungi, O Odhiambo and R Asogwa, African Economic Outlook 2017: Nigeria (African Development Bank, OECD Development Centre, UNDP, 2017). 


\section{A Brief History of Boko Haram}

According to the Global Terrorism Index, Boko Haram could be regarded as the deadliest terrorist organisation in the world in 2015, and lost only one position a year later. ${ }^{27}$ Since the beginning of the insurgency, tens of thousands of people have been killed and a large number of Nigerians have been forced to leave the country, migrating to the neighbouring territories of Chad, Niger and Cameroon. ${ }^{28}$ The intensification of brutality against the government started after the execution of the group's former leader, Mohammed Yusuf in 2009. However, at that time there was no widespread fear experienced by civilians, since the Islamist sect's primary target was Nigerian security forces. As a reaction to the insurgency, the government abused power and legitimised the excessive use of force against the fighters of Boko Haram, which has arguably paved the way for radicalisation. The blanket application of high degree of violence by the Nigerian police may have deprived the terrorist group of the possibility for engaging with politics purposefully. ${ }^{29}$

The period between 2010 and 2013 was characterised by an increasing number of civilian casualties, although the jihadist terrorist organisation attempted to issue warningswith the intent of minimising death toll in territories where attacks were planned. Furthermore, Boko Haram seemed to have enjoyed popular support during that time, since the terrorist group was likely to be viewed as an alternative to what the population, especially in the northeastern part of the country, perceived as an incompetent government. A woman from Borno stated that 'the community perception about [Boko Haram] was that [...] they are a new sect that is coming in peace because at the beginning they showed love and concern, and [they] provided things to needy people of the community' ${ }^{30}$ On the contrary, there was growing antipathy to Nigerian security forces, which was caused by their brutality in retaliation. ${ }^{31}$

Following the death of the group's founder, one of his deputies, Abubakar Shekau became the leader of Boko Haram. Over time, the name of the terrorist organisation was intertwined with the escalation of violence in Nigeria and its neighbouring countries and the significant expansion of 'legitimate' targets based on the rather narrow, Salafist interpretation of the Qur'an. The former official spokesperson of the Islamist sect, Abu Qaqa emphasised that 'even if you are a Muslim and do not abide by sharia, we will kill you'. ${ }^{32}$ Therefore, Muslims who did not comply with the group's strict version of

27 GTI, Measuring and Understanding the Impact of Terrorism (Institute for Economics and Peace, 2015); GTI, Measuring and Understanding the Impact of Terrorism (Institute for Economics and Peace, 2016).

28 C Gaffey, 'Why are over 1 million displaced persons in Nigeria too scared to go home?', Newsweek, 12 October 2017.

29 C Felter, 'Nigeria’s Battle with Boko Haram', Council on Foreign Relations, 08 August 2018.

30 Mercy Corps, 'Motivations and Empty Promises: Voices of Former Boko Haram Combatants and Nigerian Youth’, April 2016, 14.

31 S Ladbury et al., 'Jihadi Groups and State-Building: The Case of Boko Haram in Nigeria', Stability: International Journal of Security \& Development 5, no 1 (2016), 1-19.

32 M Mark, 'Boko Haram vows to fight until Nigeria establishes sharia law', The Guardian, 27 January 2012. 
Islam were growingly targeted through takfir, the practice of stating that a Muslim can be regarded as a non-believer. ${ }^{33}$

Since 2016, Boko Haram has been comprised of two factions with both of them allegedly affiliated with ISIL. In 2015, Abu Musab al-Barnawi was named as the new leader of the terrorist group. ${ }^{34}$ Despite the fact that ISIL had issued a statement about the replacement of the former leader, Shekau continued operations and claimed he was still in charge of Boko Haram, accusing al-Barnawi of attempting a coup against him. ${ }^{35}$ Following the splintering of the terrorist organisation, Shekau'sfaction could rather be characterised by the preference of indiscriminate attacks on internally-displaced people (IDPs), while al-Barnawi's faction seemed to favour more direct engagement with Nigerian security forces. ${ }^{36}$ While Boko Haram cannot be considered a unified group, the movement remains lethal and active; this is illustrated by a sharp rise in deaths in April 2020. ${ }^{37}$

Due to the fact that a sevenfold increase could be experienced in the number of civilian casualties between May and August 2017, the Nigerian military launched a comprehensive operation under the codename 'Deep Punch' in the northeast of the country. Their purpose was to decimate and drive out the remnants of Boko Haram from Sambisa Forest. The military offensive proved to be rather successful, because the terrorist organisation was distanced from urban areas and also lost territories. ${ }^{38}$ However, there is growing fear that if Boko Haram is not defeated, Europe must ready itself for a new wave of migration with terrorists arriving in the continent. Fatima Akilu, a NHS psychologist and leader of the country's de-radicalisation program argued that 'as Boko Haram gets squeezed in Nigeria by the military, what is the next stage? Embed themselves in other countries far from their homeland? That could be the plan'. ${ }^{39}$

\section{Infiltration to Europe?}

After the success of 'Deep Punch', Boko Haram retreated to more remote locations and increased theusage of soft targets, such as women, kids and refugees for committing suicide attacks. According to the Institute for Security Studies, a growing tendency can be witnessed in the group's assaults with four attacks perpetrated in 2015, ten a year later and fifteen until September 2017. ${ }^{40}$ As it can be seen in Figure 1, women, especially in SubSaharan Africa, have been responsible for a great number of suicide bombings recently,

33 O S Mahmood, 'More than propaganda: A review of Boko Haram's public messages', ISS, West Africa Report 20, March 2017.

34 BBC, 'Boko Haram in Nigeria: Abu Musab al-Barnawi named as new leader’, 03 August 2016.

35 The Sun, ‘Boko Haram allegedly split over leadership’, 17 July 2018.

36 O S Mahmood, 'Boko Haram in 2016: A highly adaptable foe', ISS Today, 07 February 2017.

37 J Campbell, 'Nigeria Security Tracker', Council on Foreign Relations, 12 October 2020.

38 Amnesty International, 'Lake Chad region: Boko Haram’s renewed campaign sparks sharp rise in civilian deaths’, 05 September 2017; J Akubo, ‘Boko Haram: Army unveils operation ‘deep punch’ for final push’, The Guardian Nigeria, 09 July 2017.

39 J W Simons, 'Boko Haram jihadists 'set to infiltrate Europe through Libya'as Nigeria's humanitarian crisis threatens NEW WAVE of illegal migration’, MailOnline, 13 February 2018.

40 A-N Mbiyozo, 'How Boko Haram specifically targets displaced people', ISS Policy Brief, 06 December 2017. 
possibly due to their ability to get close to their targets without arousing much suspicion and not being as thoroughly searched as men. ${ }^{41}$ Besides, female suicide bombers get more screen time, which is a possibility for terrorist organisations to disseminate ideology and may alsoshame males into recruitment. ${ }^{42}$

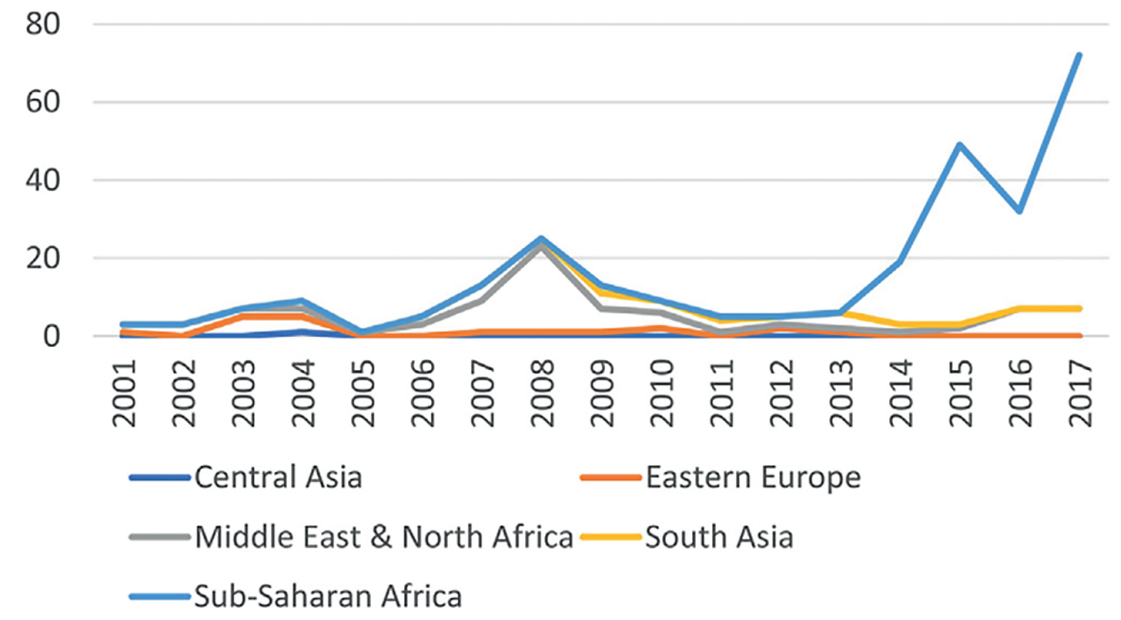

Figure 1: Female suicide bomb attacks by region 2001-2017 $7^{43}$

Currently there are approximately 294,000 Nigerian refugees, over 2 million IDPs in the country and more than 684,000 IDPs in neighbouring territories, including Cameroon, Chad and Niger. ${ }^{44}$ There is an increasing number of youths in Nigeria who started dreaming of finding work in Europe, since 'sending Euros home - a stronger currency - will make a big difference to their families'. ${ }^{45}$ Economic migration stems from the lack of job opportunities and poverty in Nigeria with the latter being exploited by Boko Haram itself. For instance, pupils of Qur'anic institutions, the almajiri are sent out to the streets in the northern part of the country to beg for two and a half hours every day in exchange for their education provided by these schools. This, in turn, may pave the way for radicalisation as kids can be approached by Boko Haram members offering them a chance for a better life. ${ }^{46}$

41 M Bloom, 'Female suicide bombers: a global trend', Daedalus 136, no 1 (2007), 94-102; M Bloom, 'Bombshells: Women and Terror', Gender Issues 28, no 1 (2011), 1-21; A Dalton and V Asal, 'Is It Ideology or Desperation: Why Do Organizations Deploy Women in Violent Terrorist Attacks?’, Studies in Conflict \& Terrorism 34, no 10 (2011), 802-819.

42 M Bloom, Dying to Kill: The Allure of Suicide Terror (New York: Columbia University Press, 2005); J Davis, Women in Modern Terrorism: From Liberation Wars to Global Jihad and the Islamic State (Lanham: Rowman \& Littlefield Publishers, 2017).

43 J Galehan, 'Instruments of violence: Female suicide bombers of Boko Haram', International Journal of Law, Crime and Justice 58 (2019), 113-123.

44 UNHCR, 'Nigeria emergency’, 2020.

45 J Burpee, ‘A Deadly Journey: Desert, Sea, Detention... On the Road to Europe’, IOM, September 2017.

46 I Aghedo and S J Eke, 'From Alms to Arms: The Almajiri Phenomenon and Internal Security in Northern Nigeria’, The Korean Journal of Policy Studies 28, no 3 (2013), 97-123. 
Religion has also been used as a recruitment tool in the Nigerian context as it can be regarded as a 'vehicle to voice [emotional or moral] outrage and provides a space for common identity that youth seek'. ${ }^{47}$ Additionally, there seems to be a connection between psychological trauma or spiritual crisis experienced by the youth and their recruitment to extremist organisations, ${ }^{48}$ which is attested by the story of Hassan, whose whole family was coerced into joining the ranks of Boko Haram and went through ideological indoctrination. He later stated that '[he had seen] a lot of people getting killed but [he had never been] selected for an operation. [He had] wanted to be selected. It would [have given him] pride, [he would have] loved it'. ${ }^{49}$

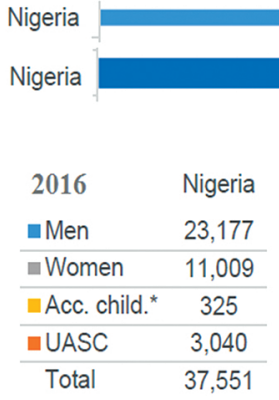

Figure 2: Nigerians of sea arrivals to Italy by gender in 2016 and 2017

Source: Compiled by the author.

As illustrated in the figure above, the majority of Nigerians arriving in Italy by sea in 2016 and $2017^{50}$ was comprised of men. The number of women was approximately half as many as their counterparts, with children accounting for less than 10 per cent of European migration flows. At first glance, this data does not seem to be staggering as 181,436 and 119,369 migrants and refugees arrived at the shores of Italy in the given years respectively and Nigerians - although one of the most represented nationalities - was only a part of the influx of individuals coming to Italy and thereby Europe by sea. ${ }^{51}$

Men are commonly utilised for traditional warfare; however, it seems that it is worth studying the potential reasons why women are increasingly used for suicide bombings by Boko Haram. Considering long-prevailing inequalities in terms of education, employment, gender development, literacy and reproductive health, countries in Sub-Saharan Africaare positioned at the bottom of the table. ${ }^{52}$ As a consequence, the life of a woman probably does not carry much value in the eyes of Boko Haram, particularly those who do not show any

Cachalia et al., ‘The dynamics of youth radicalisation', 18.

48 M Ranstorp, 'Terrorism in the Name of Religion', Journal of International Affairs 50, no 1 (1996), 41-62.

49 Simons, 'Boko Haram jihadists'.

50 Gender-based data from UNHCR could only be extracted for these specific years.

51 UNHCR, 'Nigeria emergency', 2020.

52 Human Development Report, The next frontier: Human development and the Anthropocene (New York: UNDP, 2020). 
signs of adherence to the strict, Salafist interpretation of Islam. Females are therefore seen as inexpensive commodities, serving the interests of the terrorist organisation, since the benefits Boko Haram is likely to reap after the either successful or unsuccessful outcome of their attacks is much higher than the costs entailed. ${ }^{53}$ Thanks to the combination of their efficiency in approaching targets and their expendability, it seems that women can pose a dangerous security threat to Europe, should they infiltrate the continent.

Furthermore, it could barely be possible for the countries' intelligence agencies to detect to-be attacks, if these women acted independently of one another without leaving any online traces. On the other hand, the above-mentioned example of Hassan cannot be viewed as an exceptional case, but is rather one of the thousands of similar fates. The number of unaccompanied and separated children (UASC) was nearly ten times more than of accompanied ones arriving in Italy by sea in $2016 .{ }^{54} \mathrm{~A}$ more dramatic parallel could be observed in 2017, since an almost fourteen-fold difference can be witnessed in favour of UASC. ${ }^{55}$ When they leave for abroad, although they distance themselvesfrom their place of origin physically, their close connection to religion remains. This relationmight even be strengthened due to experienced exclusion and initial alienation in the foreign land. As a result, there is growing concern about the likelihood of re-radicalisation if these disturbed children might end up in Europe. Discussing the benefits of the Nigerian de-radicalisation program, Fatima Akilu agrees that they 'don't have the resources to reach many of the children in the camps, and they certainly wouldn't get it in Europe'. ${ }^{56}$

Nevertheless, it is important to note that push factors driving migration do not always lead to youth radicalisation. Likewise, push factors driving the radicalisation of young people do not inevitably pave the way for migration either. There is no single component; individuals are rather influenced by the combination of these economic, political, social conditions and/or terrorism in countries where migrants and refugees originate from. ${ }^{57}$ The rise of youth radicalisation in Europe can be held responsible for forging a link between extremism and migration, especially since the latter might open up avenues for terrorist groups to reach their goals. However, the question remains whether these radicalised peoplecould find their way to Europe. A suspected Boko Haram member, accused of being involved in hostage-taking and several attacks against villages and schools, was arrested in Germany in 2018. ${ }^{58}$ However, concrete, well-document evidence and comprehensive further research are needed to prove correlations between radicalisation and migration.

Irregular refugee flows and migration patterns have been exploited to give vent to radicalisation in Kenyan IDP camps. ${ }^{59}$ Similarly, in the Nigerian context, it has been reported that fighters of Boko Haram have infiltrated to these camps and flows. ${ }^{60}$ According

\footnotetext{
Galehan, 'Instruments of violence'.

UNHCR, 'Italy Sea Arrivals Dashboard’, December 2016.

UNHCR, 'Italy Sea Arrivals Dashboard’, December 2017.

Simons, 'Boko Haram jihadists'.

T Reitano and P Tinti, ‘Survive and advance: The economics of smuggling refugees and migrants into Europe’, ISS Paper 289, November 2015.

58 Reuters, 'Suspected Boko Haram attacker arrested in Germany’, 26 January 2018.

59 S Hellsten, 'Radicalisation and terrorist recruitment among Kenya’s youth', Policy Note No. 1, The Nordic Africa Institute, February 2016.

60 UNHCR, 'Nigeria situation 2017’, Supplementary Appeal (Revised July 2017), January-December 2017.
} 
to the Borno State Management Agency (SEMA) 'at least nine Boko Haram insurgents and 100 accomplices were identified among 920 Nigerian refugees who returned from Cameroon'. ${ }^{61}$ Disguising themselves as refugees could be beneficial for the Islamist sect for a number of reasons. Firstly, it provides militants an opportunity to perpetrate attacks in closer proximity by pretending to need special medical attention and by the time there is a group of individuals around them, they detonate themselves. Secondly, it strengthens the self-image of the terrorist group as a cunning entity. Lastly, the lack of knowledge about people's true identity creates an atmosphere of untrustworthiness among the refugees that can easily make suspects of previously-thought victims. ${ }^{62}$

Refugees and migrants have been in the crosshairs of extremist groups, with terrorist organisations perpetrating direct or indirect attacks. They often take the form of strategic warfare, for instance bystriking IDPs or bringing about forced displacement. ${ }^{63}$ Seeking to answer the question why Boko Haram is targeting displaced persons, Kelly Greenhill's study may prove to be quite useful. She defines coercive engineered migrations as 'crossborder population movements that are deliberately created or manipulated in order to induce political, military and/or economic concessions from a target state or states' ${ }^{64}$ In her view, migration can be regarded as a strategic tool possessed by the weak, which is able to manipulate the strong. She argues that after migration has been used by the coercer to spur a conflict, the costs of the coerced in terms of managing the situation can be higher than submitting to the challenger's demands. Based on this theory, Boko Haram could be engineering migration with the intent of both overwhelming its targets' capacity and destabilising them. It could certainly be an effective strategy considering Nigerian IDPs in the neighbouring countries; however, can the terrorist group constitute a threat to European security?

Following its alignment with ISIL in 2015, there is an increased likelihood that Boko Haram could start to be engaged with migrants and refugees besides targeting IDPs. ${ }^{65}$ It appears rather probable in light of ISIL's renewed strategic focus on European migrants in recent years. Some of the methods they have used were claiming attacks they might not even have been responsible for or more importantly, infiltrating the flows of migrants. It is in the interests of ISIL to depict refugees as individuals capable of posing a security threat to Europe. It is thus absolutely elementary from their perspective that European governments do not view refugees as victims, but rather blur the distinction between them and terrorists. ${ }^{66}$ The truth is that ISIL detests people fleeing their country of origin for Europe, since it completely goes against the message they propagate about the Caliphate being a refuge. If it was truly a safe haven then what could explain the urge of hundreds

61 News24, 'Boko Haram fighters found posing as refugees: Nigeria’, 1 July 2017.

62 A B Bukarti, 'Boko Haram: How Perpetrators Impersonate Victims', Tony Blair Institute for Global Change, 21 July 2017.

63 K Koser and A E Cunningham, 'Migration, Violent Extremism and Terrorism: Myths and Realities', in GTI 2015 (Institute for Economics and Peace, 2015).

64 K M Greenhill, 'Weapons of Mass Migration: Forced Displacement as an Instrument of Coercion', Strategic Insights 9, no 1 (2010), 116.

65 A-N Mbiyozo, 'How Boko Haram specifically targets displaced people’, ISS Policy Brief, 6 December 2017.

66 M Ignatieff, 'The Refugees \& the New War', The New York Review, 17 December 2015. 
of thousands of individuals subjecting themselves to a lengthy and dangerous journey instead of remaining there?

In the period of 16-19 September 2015, twelve recordings were circulated with the intention of dissuading migrants and refugees from traveling to Europe by emphasising the high costs and risks associated with the journey. First of all, they stressed that Islamic lands shall not be left, as migrating to 'infidel territories' equals to forsaking religion and the Caliphate is the Muslim's best option for happiness anyway. Secondly, migrants were reminded that as opposed to sharia, the prevalence of human laws awaited them in Europe and refugees would gradually be forced to abandon their religion and convert to Christianity. Additionally, welcoming migrants to Europe was thought to be part of a grand scheme with Europe planning to drain the Muslim population from their countries of origin so that ISIL could be defeated. On top of that, all these irresolvable differences between the Islam world and Europe were illustrated with graphic evidence about the perceived mistreatments of individuals in the continent. ${ }^{67}$

After pledging allegiance to ISIL, there is growing concern that Boko Haram could follow suit with focusing its efforts on refugees, infiltrating migration flows and thereby creating a security threat to Europe. Since humanitarian and military support provided to Nigeria seem to be inefficient, Ayoade Olatunbosun-Alakija, Nigeria's former chief humanitarian coordinator argued that individuals may be triggered to leave the country in case the situation was not dealt with properly and immediately. Fatima Akilu agrees and claims that once hope is lost about the government's ability to remedy the crisis, a higher number of people could decide that leaving Nigeria might serve their best interests in the long term. She also stated that 'as Boko Haram comes under military pressure, it will no longer see itself as attached to Nigeria, but more connected to other parts of the world through ISIS'. ${ }^{68}$ A potential detachment from Nigeria could save up time and resources that might be channelled to Europe, in which case the terrorist group could constitute a significant threat to European security.

\section{Conclusion}

In conclusion we can state that today's mass migration and terrorism is a sort of a side effect of reactions produced by globalisation. Henceforth, migration and terrorism can never be consideredinternal problems since they can directly endangerinternational security. Imbalance, poverty, dictatorship's expansionary ambition and therelevant cultural background serve as fertile ground to expand terrorism. It is a universalthreat. Scales of attacks, qualitative and quantitative indicators of global losses, along withtransnational, professional, mobile and unscrupulous terrorist organisations are evident andsignify dangers to the overall security of every nationstate. ${ }^{69}$

67 A Zelin, 'Targeting Europe’s Refugees Is Not the Answer', Policy Analysis, Policy Watch 2524, The Washington Institute for Near East Policy, 16 November 2015.

68 Simons, 'Boko Haram jihadists'.

69 Babos, The Five Central Pillars. 
Bearing in mind the universal evidences on migration and terrorism, responding to the question whether Boko Haram constitutes a threat to European security is not as clear-cut as one might thinkat first glance. On the one hand, we could argue that the terrorist group cannot constitute a European security threat, since the majority of Nigerians arriving in Europe seemingly decided to flee their country of origin due to economic reasons. Furthermore, studying the names of refugees and migrants, it appears to be evident that most of the people originate from the southern part of Nigeria. ${ }^{70}$ However, as argued above, migration is not motivated by a single, separate component, but is rather influenced by a wide variety of push factors embedded in various processes, including political, religious and social factors. Although terrorism in the form of religious and political insurgencies could also be considereda push factor, it would have to be complemented with additional context-dependent elements. Besides, there have only been alleged cases of radicalised individuals traveling to Europe. Concrete, well-documented evidence and comprehensive further research are needed to prove correlations between radicalisation and migration.

On the other hand, we can also find evidence that Boko Haram can pose a threat to European security, which might be attested by the terrorist organisation's increased use of women as soft targets for committing suicide attacks and the potential re-radicalisation of traumatised children in Europe. Both of these trends can be rather perilous in case these people truly infiltrate the continent; the former in light of women's ability to access camps more easily and get close to their targets without arousing much suspicion, the latter due to the youth's receptiveness to radicalisation and/or religious indoctrination. Furthermore, pledging allegiance to ISIL in 2015 raises the question if Boko Haram will follow in the footsteps of Daesh, placing the strategic emphasis on refugees and migrants instead of dealing with IDPs. If so, infiltrating to European refugee flows with the intent of perpetrating attacks in the continent at a later time appears to be the next step. It would certainly increase European governments' level of cautiousness, paving the way for viewing migrants as a security threat.

However, thegradual and constant decrease in the influx of Nigerian migrants from 2018 to the presentcan be justified by the aspirations of European governments that are meant to limit and more strictly monitor the number of refugees arriving in Europe from Africa. While global security is of utmost importance, it is 'necessary to balance [security-intense responses] against humanitarian concerns and international human rights standards'. ${ }^{71}$ As a consequence, challenges should be addressed through continuous cooperationbetween African and European governments, and although international support is needed, local forces also play a pivotal role in equipping Africans with technical and educational skills as well as providing jobs for them on a regional, national or even continental level. ${ }^{72}$ Considering the pace and intensity of migration, these collaborations seemed to have come to fruition, since a significant decrease could be observed in the

70 O’Grady, 'Nigerian Migrants’; BBC, ‘A Nigerian’s nightmare’; Agbakwuru, 'FG inaugurates’.

71 Cachalia et al., 'The dynamics of youth radicalisation', 14.

72 A P Garcia and I Martin, 'EU cooperation with third countries in the field of migration', Directorate-General for Internal Policies, Policy Department, Citizens’ Rights and Constitutional Affairs, European Parliament, 2015. 
number of African migrants and refugees coming to Europe recently. ${ }^{73}$ If continuous cooperation is to remain, chances are slim that Boko Haram could constitute a threat to European security.

\section{References}

Agbakwuru, J, ‘FG inaugurates Migration Centre in Edo’. The Vanguard Nigeria, 07 March 2018. Online: www.vanguardngr.com/2018/03/fg-inaugurates-migration-centre-edo

Agbiboa, D E, 'The Nigerian burden: religious identity, conflict and the current terrorism of Boko Haram’. Conflict, Security \& Development 13, no 1 (2013), 1-29. Online: https://doi. org/10.1080/14678802.2013.770257

Aghedo, I and S J Eke, 'From Alms to Arms: The Almajiri Phenomenon and Internal Security in Northern Nigeria'. The Korean Journal of Policy Studies 28, no 3 (2013), 97-123.

Akubo, J, ‘Boko Haram: Army unveils operation ‘deep punch’for final push’. The Guardian Nigeria, 9 July 2017. Online: www.guardian.ng/news/boko-haram-army-unveils-operationdeep-punch-for-final-push/

Amnesty International, ‘Lake Chad region: Boko Haram’srenewed campaign sparks sharp rise in civilian deaths’, 05 September 2017. Online: www.amnesty.org/en/latest/news/2017/09/ lake-chad-region-boko-harams-renewed-campaign-sparks-sharp-rise-in-civilian-deaths/

Babos, T, The Five Central Pillars of European Security. Brussels: NATO Public Diplomacy Division, Budapest: Strategic and Defense Research Center, Oberammergau: NATO School, Budapest: Chartapress, 2007. Online: www.files.ethz.ch/isn/56271/07_Babos.pdf

Barungi, B, O Odhiambo and R Asogwa, African Economic Outlook 2017: Nigeria. African Development Bank, OECD Development Centre, UNDP, 2017. Online: www.afdb.org/ fileadmin/uploads/afdb/Documents/Publications/AEO_2017_Report_Full_English.pdf

BBC, 'Boko Haram in Nigeria: Abu Musab al-Barnawi named as new leader', 03 August 2016. Online: www.bbc.com/news/world-africa-36963711

BBC, ‘A Nigerian’s nightmare failed bid to migrate to Europe’, 28 April 2017. Online: www. bbc.com/news/world-africa-39731109

BBC, 'Migrant crisis: Italy minister Salvini closes ports to NGO boats', 30 June 2018. Online: www.bbc.com/news/world-europe-44668062

BBC, 'Nigeria's Katsina school abduction: Boko Haram says it took the students', 15 December 2020. Online: www.bbc.com/news/world-africa-55295701

Besenyő, J, 'Fences and Border Protection: The Question of Establishing Technical Barriers in Europe’. AARMS 16, no 1 (2017), 77-87. Online: http://real.mtak.hu/83717/1/ aarms_2017_1_07_besenyo.original_u.pdf

Bloom, M, Dying to Kill: The Allure of Suicide Terror. New York: Columbia University Press, 2005.

73 BBC, 'Migrant crisis: Italy minister Salvini closes ports to NGO boats', 30 June 2018; UNHCR, 'Italy Sea Arrivals Dashboard’, December 2018; UNHCR, 'Italy Sea Arrivals Dashboard’, December 2019; UNHCR, 'Italy Sea Arrivals Dashboard', October 2020. 
Bloom, M, 'Female suicide bombers: a global trend’. Daedalus 136, no 1 (2007), 94-102. Online: http://doi.org/10.1162/daed.2007.136.1.94

Bloom, M, 'Bombshells: Women and Terror'. Gender Issues 28, no 1 (2011), 1-21. Online: http://doi.org/10.1007/s12147-011-9098-z

Botha, A, 'Radicalisation in Kenya: Recruitment to al-Shabaab and the Mombasa Republican Council’, ISS Paper 265, September 2014. Online: https://issafrica.s3.amazonaws.com/ site/uploads/Paper265.pdf

Bukarti, A B, ‘Boko Haram: How Perpetrators Impersonate Victims’, Tony Blair Institute for Global Change, 21 July 2017. Online:www.institute.global/policy/boko-haram-howperpetrators-impersonate-victims

Burpee, J, ‘A Deadly Journey: Desert, Sea, Detention... On the Road to Europe’. IOM, September 2017. Online: http://features.iom.int/stories/deadly-journey/

Cachalia, R C, U Salifu and I Ndung'u, 'The dynamics of youth radicalisation in Africa: Reviewing the current evidence’. ISS Paper 296, August 2016. Online: https://issafrica. s3.amazonaws.com/site/uploads/paper296-1.pdf

Campbell, J, 'Nigeria Security Tracker'. Council on Foreign Relations, 12 October 2020. Online: www.cfr.org/nigeria/nigeria-security-tracker/p29483

Dalton, A and V Asal, 'Is It Ideology or Desperation: Why Do Organizations Deploy Women in Violent Terrorist Attacks?' Studies in Conflict \& Terrorism 34, no 10 (2011), 802-819. Online: http://doi.org/10.1080/1057610X.2011.604833

Davis, J, Women in Modern Terrorism: From Liberation Wars to Global Jihad and the Islamic State. Lanham: Rowman \& Littlefield Publishers, 2017.

DTM, 'Libya’s Migrant Report', Flow Monitoring, Round 17, January-February 2018. Online: https://displacement.iom.int/system/tdf/reports/DTM\%20Libya\%20 Round\%2017\%20Migrant\%20Report\%20\%28Jan-Feb\%202018\%29\%281\%29. pdf?file=1\&type=node \&id=3106

European Commission, Standard Eurobarometer 89 - Wave EB89.1. Kantar Public Brussels on behalf of TNS opinion \& social, Survey requested and co-ordinated by the European Commission, Directorate-General for Communication, Fieldwork, March 2018.

Eurostat, 'Asylum and new asylum applicants: monthly data', 2018. Online: https://ec.europa. eu/eurostat/tgm/table.do?tab=table\&init=1\&language=en\&pcode=tps00189\&plugin=1

Felter, C, 'Nigeria’s Battle with Boko Haram', Council on Foreign Relations, 08 August 2018. Online: www.cfr.org/backgrounder/nigerias-battle-boko-haram

Flint, C, Introduction to Geopolitics. New York: Routledge, 2011. Online: https://doi. org/10.4324/9780203816752

Gaffey, C, 'Why are over 1 million displaced persons in Nigeria too scared to go home?' Newsweek, 12 October 2017. Online: www.newsweek.com/boko-haram-idps-refugeesnigeria-683001

Galehan, J, 'Instruments of violence: Female suicide bombers of Boko Haram'. International Journal of Law, Crime and Justice 58 (2019), 113-123. Online: https://doi.org/10.1016/j. ijlcj.2019.04.001

Garcia, A P and I Martin, 'EU cooperation with third countries in the field of migration', Directorate-General for Internal Policies, Policy Department, Citizens’ Rights and 
Constitutional Affairs, European Parliament, 2015. Online: www.europarl.europa.eu/ RegData/etudes/STUD/2015/536469/IPOL_STU\%282015\%29536469_EN.pdf

Greenhill, K M, 'Weapons of Mass Migration: Forced Displacement as an Instrument of Coercion’. Strategic Insights 9, no 1 (2010). Online: https://doi. org/10.7591/9780801458668

GTI, Measuring and Understanding the Impact of Terrorism. Institute for Economics and Peace, 2015. Online:www.visionofhumanity.org/wp-content/uploads/2020/10/2015-GlobalTerrorism-Index-Report.pdf

GTI, Measuring and Understanding the Impact of Terrorism. Institute for Economics and Peace, 2016. Online: www.economicsandpeace.org/wp-content/uploads/2016/11/GlobalTerrorism-Index-2016.2.pdf

Hellsten, S, 'Radicalisation and terrorist recruitment among Kenya’s youth'. Policy Note No. 1, The Nordic Africa Institute, February 2016. Online: http:/nai.diva-portal.org/smash/get/ diva2:906144/FULLTEXT01.pdf

Hooper, K, 'European Leaders Pursue Migration Deals with North African Countries, Sparking Concerns about Human Costs’. Migration Policy Institute, 17 December 2017. Online: www.migrationpolicy.org/article/top-10-2017-issue-3-european-leaders-pursue-migrationdeals-north-african-countries

Human Development Report, The next frontier: Human development and the Anthropocene. New York: UNDP, 2020. Online: http://hdr.undp.org/sites/default/files/hdr2020.pdf

Ignatieff, M, 'The Refugees \& the New War', The New York Review, 17 December 2015. Online: www.nybooks.com/articles/2015/12/17/refugees-and-new-war/

Inyang, I, ‘Boko Haram is broke - UN Envoy’. Daily Post, 08 February 2017. Online: https:// dailypost.ng/2017/02/08/boko-haram-broke-un-envoy/

IOM, 'Migration Trends Across the Mediterranean: Connecting the Dots', Altai Consulting for IOM MENA Regional Office, June 2015. Online: https:/publications.iom.int/system/files/ altai_migration_trends_accross_the_mediterranean.pdf

IOM, 'World Migration Report 2018’. Online: www.iom.int/sites/default/files/country/docs/ china/r5_world_migration_report_2018_en.pdf

IOM UN Migration, 'Mediterranean Migrant Arrivals Reach 110,833 in 2018; Deaths Reach 2, 160’, 12 November 2018. Online: https://reliefweb.int/sites/reliefweb.int/files/resources/ Mediterranean\%20Migrant\%20Arrivals\%20Reach\%20110.pdf

Isike, C and E Isike, 'Migration and the geopolitics of Boko Haram terrorism in Nigeria'. Strategic Review for Southern Africa 40, no 2 (2018), 34-51. Online: https://doi. org/10.35293/srsa.v40i2.183

Koser, K and A E Cunningham, 'Migration, Violent Extremism and Terrorism: Myths and Realities', in GTI 2015. Institute for Economics and Peace, 2015. Online: www.files.ethz. ch/isn/194968/Global-Terrorism-Index-2015.pdf

Ladbury, S, H Allamin, Ch Nagarajan, P Francis and U O Ukiwo, 'Jihadi Groups and StateBuilding: The Case of Boko Haram in Nigeria’. Stability: International Journal of Security \& Development 5, no 1 (2016), 1-19. Online: https://doi.org/10.5334/sta.427

Loada, A and P Romaniuk, 'Preventing Violent Extremism in Burkina Faso: Toward National Resilience Amid Regional Insecurity’. Global Center on Cooperative Security, June 
2014. Online: www.globalcenter.org/wp-content/uploads/2014/07/BF-Assessment-Engwith-logos-low-res.pdf

Mahmood, O S, 'More than propaganda: A review of Boko Haram's public messages'. ISS, West Africa Report 20, March 2017. Online: https://issafrica.s3.amazonaws.com/site/uploads/ war20.pdf

Mahmood, O S, 'Boko Haram in 2016: A highly adaptable foe’. ISS Today, 07 February 2017. Mark, M, 'Boko Haram vows to fight until Nigeria establishes sharia law'. The Guardian, 27 January 2012. Online: www.theguardian.com/world/2012/jan/27/boko-haram-nigeriasharia-law

Mbiyozo, A-N, 'How Boko Haram specifically targets displaced people’. ISS Policy Brief, 6 December 2017. Online: https://issafrica.s3.amazonaws.com/site/uploads/policybrief109. pdf

Mercy Corps, 'Motivations and Empty Promises: Voices of Former Boko Haram Combatants and Nigerian Youth', April 2016. Online: www.mercycorps.org/sites/default/files/2019-11/ Motivations\%20and\%20Empty\%20Promises_Mercy\%20Corps_Full\%20Report_0.pdf

Moten, A R, 'Understanding Terrorism: Contested Concept, Conflicting Perspectives and Shattering Consequences'. Intellectual Discourse 18, no 1 (2010), 35-63.

NBS, '2019 Poverty and Inequality in Nigeria: Executive Summary'. National Bureau of Statistics, 2019. Online: https://nigerianstat.gov.ng/

News24, 'Boko Haram fighters found posing as refugees: Nigeria', 1 July 2017. Online: www. news24.com/news24/Africa/News/boko-haram-fighters-found-posing-as-refugeesnigeria-20170701

O’Grady, S, ‘Nigerian Migrants Get a Welcome Home. Jobs Are Another Story’. New York Times, 08 January 2018. Online: www.nytimes.com/2018/01/08/world/africa/migrantsnigeria-libya.html

Okeyim, M O, The State and Migration of Nigerians into the European Union to Live in Spain. Doctoral thesis, University of Alicante, 2012. Online: https://rua.ua.es/dspace/ bitstream/10045/28375/1/Tesis_Okiri_Okeyim.pdf

Pettiford, L and D Harding, Terrorism: The New World War. London: Arcturus Publishing Limited, 2003.

Pew Research Center, 'At Least a Million Sub-Saharan Africans Moved to Europe Since 2010', 22 March 2018. Online: www.pewresearch.org/global/2018/03/22/at-least-a-million-subsaharan-africans-moved-to-europe-since-2010/

Poushter, J, 'In nations with significant Muslim populations, much disdain for ISIS', Pew Research Center, 17 November 2015. Online: www.pewresearch.org/fact-tank/2015/11/17/ in-nations-with-significant-muslim-populations-much-disdain-for-isis/

Ranstorp, M, ‘Terrorism in the Name of Religion'. Journal of International Affairs 50, no1 (1996), 41-62.

Reitano, T and P Tinti, 'Survive and advance: The economics of smuggling refugees and migrants into Europe’. ISS Paper 289, November 2015. Online: https://issafrica. s3.amazonaws.com/site/uploads/Paper289-2.pdf

Reuters, 'Suspected Boko Haram attacker arrested in Germany’, 26 January 2018. Online: www. reuters.com/article/us-nigeria-security-germany-idUSKBN1FF1X4 
Simons, J W, ‘Boko Haram jihadists ‘set to infiltrate Europe through Libya’ as Nigeria’s humanitarian crisis threatens NEW WAVE of illegal migration'. MailOnline, 13 February 2018. Online: www.dailymail.co.uk/news/article-5382499/Boko-Haram-jihadists-infiltrateEurope-Libya.html

The Sun, ‘Boko Haram allegedly split over leadership’, 17 July 2018. Online: www. sunnewsonline.com/shekau-boko-haram-split-leadership/

UNHCR, 'Italy Sea Arrivals Dashboard', December 2016. Online: https://data2.unhcr.org/en/ documents/details/53356

UNHCR, ‘Italy Sea Arrivals Dashboard’, December 2017. Online: https://data2.unhcr.org/en/ documents/details/61547

UNHCR, 'Nigeria situation 2017’, Supplementary Appeal (Revised July 2017), JanuaryDecember 2017. Online: https://reporting.unhcr.org/sites/default/files/Revised\%20 2017\%20SB\%20Nigeria\%20Situation_FINAL.pdf

UNHCR, 'Italy Sea Arrivals Dashboard', December 2018. Online: https://data2.unhcr.org/en/ documents/details/67555

UNHCR, 'Italy Sea Arrivals Dashboard’, December 2019. Online: https://data2.unhcr.org/en/ documents/details/73536

UNHRC, 'Italy Sea Arrivals Dashboard', October 2020. Online: https://data2.unhcr.org/en/ documents/details/83169

UNHCR, 'Nigeria emergency’, 2020. Online: www.unhcr.org/nigeria-emergency.html

Weber, H, 'Can Violent Conflicts Explain the Recent Increase in the Flow of Asylum Seekers From Africa Into Europe?’ Journal of Immigrant \& Refugee Studies 17, no 4 (2019), 405-424. Online: https://doi.org/10.1080/15562948.2018.1517424

Zelin, A, 'Targeting Europe’s Refugees Is Not the Answer', Policy Analysis, Policy Watch 2524, The Washington Institute for Near East Policy, 16 November 2015. Online: www. washingtoninstitute.org/policy-analysis/targeting-europes-refugees-not-answer 